\title{
Knowledge of Ebola virus disease among students at AIMST University, Kedah, Malaysia
}

Lely Lubna Alaydrus, ${ }^{1,2}$ Nurul Atikah Binti Mohamed Hanaphi, ${ }^{3}$ Nur Anisa Binti Mohamed Haniffah, ${ }^{4}$ Nurulain Binti Sukeri, ${ }^{5}$ Liling Chaw, ${ }^{6}$ Lin Naing ${ }^{6}$

pISSN: 0853-1773 • elSSN: 2252-8083 https://doi.org/10.13181/mji.v28i2.2441 Med J Indones. 2019;28:162-6

Received: December 14, 2017

Accepted: April 09, 2019

\section{Authors' affiliations:}

${ }^{1}$ Community Medicine Unit, Faculty of Medicine, AIMST University, Kedah, Malaysia, ${ }^{2}$ Magister Management, Universitas Mercu Buana, Jakarta, Indonesia, ${ }^{3}$ Sultan Haji Ahmad Shah Hospital, Temerloh, Pahang, Malaysia, ${ }^{4}$ Kulim Hospital, Kulim, Kedah, Malaysia, ${ }^{5}$ Tengku Ampuan Afzan Hospital, Kuantan, Malaysia, ${ }^{6}$ PAPRSB Institute of Health Sciences, Universiti Brunei Darussalam, Bandar Seri Begawan, Brunei Darussalam

\section{Corresponding author:}

Lely Lubna Alaydrus

Universitas Mercu Buana, Jalan Meruya

Selatan Nomor 1, West Jakarta 11650, DKI Jakarta, Indonesia

Tel/Fax: +62-21-5840816/+62-21-5840813

E-mail: lubna.al.idrus@gmail.com/

5117110188@student.mercubuana.ac.id

\begin{abstract}
BACKGROUND Information on Ebola virus disease is need to be disseminated especially in health science students. The aim of the study was to assess the level of knowledge of Ebola virus disease (EVD) among students at The Asian Institute of Medical, Science and Technology (AIMST) University.
\end{abstract}

METHODS This research was a cross-sectional study of 250 year-1- to year-4-students selected through the stratified sampling method from five health science faculties at AIMST University. Independent variables included students' age, gender, faculty of origin, source of information, and participation in seminars or conferences, while the dependent variable was the students' knowledge of EVD. Data were obtained using a self-administered questionnaire.

RESULTS The majority of the students did not have adequate knowledge of EVD (77.2\%). The level of knowledge of EVD was significantly associated with faculty of origin ( $p=$ 0.014) only and not associated with other variables, such as sociodemographic factors, source of information, and participation in seminars or conferences.

CONCLUSIONS Information on EVD needs to be disseminated more intensively among university students due to the current lack of knowledge of the disease.

KEYWORDS Ebola virus, knowledge, Malaysia, students
Ebola virus disease (EVD) is a serious and fatal illness in humans caused by the Ebola virus from the Filoviridae family. ${ }^{1}$ It is transmitted from infected wild animals, such as chimpanzees, fruit bats, monkeys, gorillas, and porcupines, to humans through direct contact with blood, secretions, bodily fluids, organs, and consumption of raw meats. Human-to-human transmission occurs directly through contact with the blood, bodily fluids, or organs of infected people and indirectly through exposure to materials that may have been touched by infected persons. i.e., the incubation period of EVD, i.e., the period between point of infection and the time a person becomes symptomatic, ranges from one week to three weeks.
An infected person during this period is highly contagious and, hence, can transmit the infection when they travel to other countries. ${ }^{2-5}$

The case fatality rate of EVD reached $90 \%$ during the 2014-2016 outbreak in West Africa, with approximately 11,308 deaths reported in Guinea, Sierra Leone, and Liberia. With massive international effort, this two-year crisis was finally declared to have ended in June $2016 .^{6}$ However, responses to this global outbreak were delayed due to a lack of experience among West African health workers who had never dealt with an Ebola outbreak and did not know what they were dealing with in the first few critical months. Insufficient knowledge 
and surveillance capacity caused local systems to respond very slowly in recognizing and responding to Ebola outbreaks, resulting in uncontained disease spread, widespread infection, and countless lives lost. Countries outside the African region, including Southeast Asian countries, should learn from this experience to better prepare themselves to curb Ebola spread and prevent potential pandemics.5,7

Another EVD outbreak occurred in the Democratic Republic of the Congo on May 2018. On the $8^{\text {th }}$ of May 2018, the Ministry of Health of the Democratic Republic of the Congo notified the World Health Organization (WHO) of an EVD outbreak in Bikoro Health Zone, Equateur Province, Congo. From then until the $24^{\text {th }}$ of May 2018, 35 cases of EVD were confirmed from 54 suspected cases; 3 cases occurred among health care workers. This episode was the ninth EVD outbreak in the Democratic Republic of the Congo over the last four decades. ${ }^{8}$ Some countries have implemented entry screening for international travelers coming from Democratic Republic of the Congo, but the WHO advises against the application of any travel or trade restrictions since the WHO Director-General under the International Health Regulations did not declare the recent EVD outbreak in the Democratic Republic of the Congo as a Public Health Emergency of International Concern on the $18^{\text {th }}$ of May 2018 in Geneva. ${ }^{8}$

EVD has been detected in other African countries, such as Nigeria, Mali, and Senegal, and found to spread beyond the African continent to the United States, England, Italy, and Spain..$^{9-11}$ Although these outbreaks emerged in Africa, EVD remains a concern in the Southeast Asian region because of its high fatality rate. Government and public health organizations in Southeast Asian countries have enforced and improved surveillance and detection methods against all potential incoming transfers of EVD. ${ }^{6}$ The Ebola epidemic has been handled internationally by employing health workers from outside Africa. Qualified and knowledgeable medical personnel from Southeast Asian countries can take part in the eradication or prevention of EVD. 5

No EVD case has yet been detected in Southeast Asian countries. However, suspected cases, including 7 cases in the Philippines; 1 case each in Vietnam, Myanmar, and Indonesia; 9 cases in Malaysia; 3,000 cases in Thailand; and 2 cases in Singapore, were reported in 2014; all of these cases were subsequently confirmed negative. ${ }^{12}$ All countries have implemented strategies to prevent the spread of EVD by strengthening surveillance at airports and issuing travel advisories. The Ministry of Health of all governments has conducted intensive preventive measures at arrival and departure points for travelers, especially those from Guinea, Liberia, Sierra Leone, Nigeria, Senegal, and the Democratic Republic of the Congo. ${ }^{12}$

In response to the 2014-2016 outbreak in West Africa, the Ministry of Health of Malaysia has implemented preventive measures against the spread of EVD at entry points, mainly in international airports in Selangor, Penang, Johor Bahru, and Kota Kinabalu. All travelers are monitored using a body temperature scanner. Incoming travelers via the land borders of Thailand and Singapore in vehicles are checked, and additional monitoring systems have been installed in Padang Besar, Perlis, Rantau Panjang, and Kelantan. Travelers with high fever and who had been in any country affected by Ebola within the last three weeks are quarantined. Moreover, public health personnel have conducted simulated exercises to prepare themselves in the event they encounter a confirmed Ebola case in the country. ${ }^{13,14}$

Disseminating information on EVD to the community and determining the level of knowledge of university students, especially health science students, regarding EVD is necessary. This study was conducted to assess the level of knowledge of health science students in a private university in Kedah State, Malaysia, of EVD and its association with sociodemographic factors.

\section{METHODS}

This cross-sectional study was carried out at AIMST University in Kedah, Malaysia, from January 2015 to March 2015 in five health science faculties or schools at the university, namely, Faculty of Medicine, Faculty of Dentistry, Faculty of Pharmacy, School of Physiotherapy, and School of Nursing. Using the non-proportionate stratified sampling technique, 50 students from each faculty or school were selected. Independent variables included faculty of origin, gender, ethnicity, age group, source of information, and participation in seminars or conferences, while the dependent variable was level of knowledge of EVD. This research project received ethical approval from the Research Ethics Committee (Human) AIMST 
University, Malaysia on $16^{\text {th }}$ April 2015 (Ref No: FOM/ SSM/2015/005).

Data were obtained using a self-administered questionnaire. Content validity was determined by three tropical medicine experts from the Faculty of Medicine. Prior to data collection, a pilot survey was conducted among 30 non-health science students from the same university to test the reliability of the questionnaire. After the test, a revision, and a retest, the questionnaire was found to be valid and reliable with a Cronbach's alpha of 0.705 .

The questionnaire included 11 items assessing the level of students' knowledge of EVD, including its cause (items 1 and 2), transmission (items 3-7), symptoms (item 8), prevention (items 9 and 10), and prognosis (item 11). Each correct answer to the knowledge-related question was given a score of one, while incorrect and "do not know" answers were given a score of zero. For data analysis, level of knowledge was categorized as "good" when the total score was greater than or equal to six and "poor" when the total score was less than six.

Data were analyzed using Statistical Package for the Social Sciences (SPSS) version 22, and demographic data and level of knowledge of EVD are presented using descriptive statistics. Associations between the dependent and independent variables were tested using the chi-squared test. An association with $p<0.05$ was considered statistically significant.

\section{RESULTS}

A total of 250 students (50 students from each faculty/school) participated in this study. The majority of the participants were female (63.2\%), Malays (38.4\%), and above 21 years of age (70.8\%). The mean (SD) knowledge score of the sample is 4.0 (1.84), two points lower than the cut-off value that was set for adequate level of knowledge. About 3/4 (77.2\%) of the participants had poor knowledge of EVD. As many as four (1.6\%) participants obtained zero scores, and none of the respondents obtained a perfect score.

Table 1 shows that less than half of the participants gave correct answers to all themes of knowledge-related questions. A relatively high proportion of participants answered the questions "Ebola can cause disease in human and non-human primates" (49.6\%), "Ebola can spread through air" (38.4\%), "Ebola can be transmitted sexually" (46.8\%), "Ebola can be spread by mosquitoes" (46.0\%), and "there is a vaccine that can stop adults from getting Ebola" (49.6\%) incorrectly. Nearly half of the

Table 1. Knowledge of EVD

\begin{tabular}{|c|c|c|c|}
\hline \multirow{2}{*}{ Questions } & \multicolumn{3}{|c|}{$\mathrm{n}(\%)$} \\
\hline & Yes & No & I don't know \\
\hline \multicolumn{4}{|l|}{ Cause } \\
\hline Ebola is caused by infection with a virus of the family Filoviridae, genus Ebola virus. & $118(47.2)^{*}$ & $61(24.4)$ & $71(28.4)$ \\
\hline $\begin{array}{l}\text { Ebola can cause disease in humans and nonhuman primates (monkeys, gorillas, and } \\
\text { chimpanzees). }\end{array}$ & $67(26.8)^{*}$ & $124(49.6)$ & $59(23.6)$ \\
\hline Transmission Ebola virus disease is spread through air. & $82(32.8)$ & $96(38.4)^{*}$ & $72(28.8)$ \\
\hline Ebola virus disease can be transmitted sexually. & $59(23.6)^{*}$ & $117(46.8)$ & $74(29.6)$ \\
\hline Mosquitoes can spread Ebola. & $60(24.0)$ & $115(46.0)^{*}$ & $75(30.0)$ \\
\hline Ebola is present in semen of a recovered patient up to 7 weeks. & $61(24.4)^{*}$ & $93(37.2)$ & $96(38.4)$ \\
\hline Only a symptomatic patient can transmit Ebola virus disease. & $124(49.6)^{*}$ & $71(28.4)$ & $55(22.0)$ \\
\hline \multicolumn{4}{|l|}{ Symptom } \\
\hline Ebola virus disease starts with; fever, headache, muscle pain without bleeding. & $102(40.8)^{*}$ & $71(28.4)$ & $77(30.8)$ \\
\hline \multicolumn{4}{|l|}{ Prevention } \\
\hline There is a vaccine that can stop adults from getting Ebola. & $52(20.8)$ & $124(49.6)^{*}$ & $74(29.6)$ \\
\hline Washing hands regularly with soap and water can prevent Ebola disease. & $52(20.8)^{*}$ & $84(33.6)$ & $114(45.6)$ \\
\hline \multicolumn{4}{|l|}{ Prognosis } \\
\hline Recovery from Ebola virus diasease is possible. & $88(35.2)^{*}$ & $70(28.0)$ & $92(36.8)$ \\
\hline
\end{tabular}

EVD=Ebola virus disease

* correct answer 
Table 2. Sources of information regarding Ebola

\begin{tabular}{|c|c|c|c|c|}
\hline \multirow{2}{*}{ Source of information } & & \multicolumn{2}{|c|}{ Level of knowledge } & \multirow[b]{2}{*}{$p^{\ddagger}$} \\
\hline & & $\begin{array}{c}\text { Good* } \\
\text { n (\%) }\end{array}$ & $\begin{array}{l}\text { Poor }^{+} \\
\text {n (\%) }\end{array}$ & \\
\hline \multirow[t]{2}{*}{ TV } & Yes & $51(22.5)$ & $176(77.5)$ & \\
\hline & No & $6(26.1)$ & 17 (73.9) & 0.693 \\
\hline \multirow[t]{2}{*}{ Newspaper } & Yes & $45(22.0)$ & $160(78.0)$ & \\
\hline & No & $12(26.7)$ & $33(73.3)$ & 0.495 \\
\hline \multirow[t]{2}{*}{$\begin{array}{l}\text { School/university } \\
\text { health clinic }\end{array}$} & Yes & $5(45.5)$ & $6(54.5)$ & \\
\hline & No & $52(21.8)$ & $187(78.2)$ & $0.132^{\S}$ \\
\hline \multirow[t]{2}{*}{$\begin{array}{l}\text { Poster, brochure, } \\
\text { pamphlet from clinic }\end{array}$} & Yes & $4(20.0)$ & $16(80.0)$ & \\
\hline & No & $53(23.0)$ & $177(77.0)$ & $1.000^{\S}$ \\
\hline \multirow[t]{2}{*}{ Families, friends } & Yes & $8(40.0)$ & $12(60.0)$ & \\
\hline & No & $49(21.3)$ & $181(78.7)$ & $0.090^{\S}$ \\
\hline \multirow[t]{2}{*}{ Books } & Yes & $0(0.0)$ & $8(100)$ & \\
\hline & No & $57(23.6)$ & $185(76.4)$ & $0.204^{\S}$ \\
\hline \multirow[t]{2}{*}{$\begin{array}{l}\text { Participation in } \\
\text { seminar or conference }\end{array}$} & Yes & $7(35.0)$ & $13(65.0)$ & \\
\hline & No & $50(21.7)$ & $180(78.3)$ & 0.175 \\
\hline
\end{tabular}

*score 6 and above; 'score below 6; ${ }^{\ddagger}$ chi-squared test; §Fisher's exact test

participants did not know that washing hands can prevent the spread of Ebola (45.6\%).

Table 2 shows the respondents' sources of information on Ebola. Television (90.8\%) and newspaper (82.0\%) were the two main sources of information cited by the majority of the participants. Less than $1 / 10$ of the participants (8.0\%) ever attended a seminar or conference on Ebola. When asked about the type of awareness campaign they wanted to attend in the future to learn more about the disease, most respondents (94.0\%) chose a health talk (Table 3). No association was found between sources of information and level of knowledge of EVD (Table 2). The chi-squared test revealed that only faculty of origin is associated with students' level of EVD knowledge ( $p$ $=0.014$ ) (Table 4).

\section{DISCUSSION}

The majority of the students surveyed had poor knowledge of EVD (77.2\%). This finding is similar to the results of previous studies conducted in Malaysia, Pakistan, Hungary, and England. A study carried out by Abubakar and Sulaiman ${ }^{14}$ among university
Table 3. Type of Ebola awareness campaign preferred

\begin{tabular}{lcc}
\hline \multirow{2}{*}{$\begin{array}{l}\text { Type of campaign for Ebola } \\
\text { awareness }\end{array}$} & \multicolumn{2}{c}{$\mathrm{n}(\%)$} \\
\cline { 2 - 3 } & Yes & No \\
\hline Health talk on Ebola & $235(94.0)$ & $15(6.0)$ \\
Special event on TV & $121(48.4)$ & $129(51.6)$ \\
Workshop on Ebola & $101(40.4)$ & $149(59.6)$ \\
\hline
\end{tabular}

students in Universiti Sains Malaysia showed that the majority of the students surveyed had poor knowledge regarding EVD (median knowledge score <50\%). A study conducted by Salman et al $^{15}$ among Pakistani university students showed that most students also have poor knowledge of EVD (91.8\%). Károlyházy et al ${ }^{16}$ conducted a study among dental students in Hungary and reported poor knowledge of EVD. Moreover, Fazekas et $\mathrm{al}^{17}$ conducted a study among junior doctors in England and showed that surveyed doctors have poor awareness regarding EVD.

The poor knowledge of EVD determined in this research may be attributed to the fact that an Ebola outbreak has never occurred in Malaysia or any Southeast Asian country; thus, health sciences students may not consider this disease a threat and priority. University students should be encouraged to gain information on EVD and prepare themselves with knowledge that can help them prevent Ebola outbreaks in Malaysia. At AIMST University, medical students must conduct a community health campaign during their Community Medicine Posting in year $3 .{ }^{18}$ This program is conducted routinely every month by a group of 25-30 year-3 medical students. At the end of the posting, students are requested to organize a health campaign at villages near the university. Medical students invite students from other faculties, such as students from the Faculty of Dentistry, Faculty of Pharmacy, School of Physiotherapy, and School of Nursing, to help them organize the program. The campaigns aim to disseminate health information, including common health issues related to hypertension, diabetes, maternal and child health issues, and dengue disease. The information regarding EVD in these campaigns was recommended to be include to increase the level of knowledge of the community.

The health science students was recommended to organize a similar campaign within the campus to disseminate information on EVD to non-health science 
Table 4. Association between sociodemographic factors and level of knowledge

\begin{tabular}{lcccc}
\hline \multirow{2}{*}{$\begin{array}{l}\text { Sociodemographic } \\
\text { factors }\end{array}$} & \multicolumn{3}{c}{ Level of knowledge } & \multirow{2}{*}{$p^{\ddagger}$} \\
\cline { 2 - 3 } Faculty & Good* $\mathrm{n}(\%)$ & Poor $^{\dagger} \mathrm{n}(\%)$ & \\
\hline Medicine & $16(31.4)$ & $35(68.6)$ & 0.014 \\
\hline Dentistry & $15(30.0)$ & $35(70.0)$ & \\
\hline Pharmacy & $3(6.1)$ & $46(93.9)$ & \\
\hline Physiotherapy & $14(27.5)$ & $37(72.5)$ & \\
\hline Nursing & $9(18.4)$ & $40(81.6)$ & \\
\hline Gender & & & \\
\hline Male & $16(17.4)$ & $76(82.6)$ & 0.120 \\
\hline Female & $41(25.9)$ & $117(74.1)$ & \\
\hline Ethnicity & & & \\
\hline Malay & $20(20.8)$ & $76(79.2)$ & 0.313 \\
\hline Chinese & $25(28.1)$ & $64(71.9)$ & \\
\hline Indian & $12(18.5)$ & $53(81.5)$ & \\
\hline Age (years) & & & \\
\hline$\leq 21$ & $15(20.5)$ & $58(79.5)$ & 0.586 \\
\hline$>21$ & $42(23.7)$ & $135(76.3)$ & \\
\hline
\end{tabular}

*score 6 and above; ${ }^{\dagger}$ score below 6 ; ${ }^{\ddagger}$ chi-squared test Risk estimate statistics could not be computed. These statistics are only computed for $2 \times 2$ tables without empty cells.

students and staff at AIMST University. For example, a one-day health talk can be conducted alternately in each faculty or school at the university to improve students' knowledge of EVD. Health talks are a good way to improve knowledge, ${ }^{19}$ as recommended by the majority of the participants in this study (94\%).

This study presents a number of limitations that must be addressed in future work. First, this study was conducted in only one university and did not include multivariate analysis. Second, the sampling method could be improved by using a proportionate stratified sampling method to obtain a sample size proportionate to the population size.

In conclusion, AIMST university students have poor knowledge regarding EVD. Community-based health campaigns with health talks in campus are recommended to improve the current level of knowledge of EVD.

\section{Conflict of Interest}

There is no conflict of interest in this study.

\section{Acknowledgment}

None.
Funding Sources

None.

\section{REFERENCES}

1. World Health Organization. Ebola Virus Disease [cited 2015 August 13]. Available from: http://www.who.int/mediacentre/ factsheets/fs103/en/.

2. Judson S, Prescott J, Munster V. Understanding Ebola virus transmission. Viruses. 2015;7(2):511-21.

3. Rewar S, Mirdha D. Transmission of ebola virus disease: an overview. Ann Glob Health. 2014;80(6):444-51.

4. Centers for Disease Control and Prevention. Ebola transmission [updated 2015 July 22; cited 2015 August 14]. Available from: https://www.cdc.gov/vhf/ebola/transmission/index.html.

5. Sun L, Dennis B, Bernstein L, Achenbach J. Out of control. How the world's health organization failed to stop Ebola disaster. Available from: https://www.washingtonpost.com/sf/ national/2014/10/04/how-ebola-sped-out-of-control/.

6. Rajiah K, et al. Prevalence and Current Approaches of Ebola Virus Disease in ASEAN Countries 2014 [cited 2015 August 17]. Available from: https://www.ncbi.nlm.nih.gov/pmc/articles/ PMC4606258/.

7. Hoffman SJ, Silverberg SL. Delays in global disease outbreak responses: lessons from $\mathrm{H}_{1} \mathrm{~N}_{1}$, Ebola, and Zika. Am J Public Health. 2018;108(3):329-33.

8. World Health Organization. Ebola situation reports: Democratic Republic of the Congo. Available from: http:// www.who.int/ebola/situation-reports/drc-2018/en/Centers for Disease Control and Prevention. Ebola Virus Disease 2014 [cited 2015 May 15]. Available from: https://www.cdc.gov/vhf/ ebola/about.html.

9. Gatherer D. The 2014 Ebola virus disease outbreak in West Africa. J Gen Virol. 2014;95:1619-24.

10. Hunt R. Ebola virus. [updated 2017 April 15; cited 2017 October 19]. Available from: http://www.microbiologybook.org/mhunt/ ebola.htm.

11. Rajiah K, San KP, Jiun TW, May TA, Neng YC, Seng HK, et al. Prevalence and current approaches of Ebola virus disease in ASEAN countries. J Clin Diagn Res. 2015;9(9):LE01-6.

12. The Straits Times. Malaysia steps up Ebola screening at major airports [cited 2014 October 20]. Available from: http:// www.straitstimes.com/asia/se-asia/malaysia-steps-up-ebolascreening-at-major-airports.

13. Rajiah K, Maharajan MK, Zakiah S, Tan CL, Tan Yen Pei A, Wong San Ying A. Emergency preparedness and perceived response of Malaysian health care providers. Am J Infect Control. 2016;44(12):1720-2.

14. Abubakar U, Sulaiman SA. Knowledge of Ebola virus disease: an evaluation of university students and staff regarding the current Ebola issue around the globe. Arch Pharm Pract. 2015;6(4):8592.

15. Salman M, Shehzadi N, Hussain K, Saleem F, Khan MT, Asif N, et al. Knowledge of Ebola virus disease among a university population: a cross-sectional study. Am J Infect Control. 2017;45(2):e23-5.

16. Károlyházy K, Fazekas B, Fazekas J, Hermann P, Márton K. Ebola virus disease: awareness among dental students in Hungary. Acta Microbiol Immunol Hung. 2016;63(3):325-37.

17. Fazekas B, Fazekas J, Moledina M, Fazekas B, Karolyhazy K. Ebola virus disease: awareness among junior doctors in England. J Hosp Infect. 2015;90(3):260-2.

18. Faculty of Medicine (FOM). Handbook for year 1-5 MBBS Students. 2014. AIMST University, Kedah, Malaysia.

19. Prozesky, D. Giving a health talk. Community Eye Health. 2014;27(88):76. 